\title{
ADAPTIVE OPERATION ALGORITHM OF AN INTELLIGENT HUMIDITY SENSOR
}

\author{
S. V. Artemova, A. A. Artemov, P. A. Podkhvatilin, I. Yu. Koshelev \\ Department "Design of Electronic and Microprocessor-Based Systems", TSTU; \\ sartemova@yandex.ru
}

Keywords: adaptive algorithm; intelligent humidity sensor; neural network; sensor failure.

Abstract: The article describes an adaptive operation algorithm of an intelligent humidity sensor that allows determining a moisture content of a paste material with a reasonable accuracy in case of failure of device components.

Intelligent sensors are traditionally improved by developing their designs and elements, as well as by using methods for the description and subsequent analysis of measuring procedures [1]. An analytical approach is commonly used in the synthesis of intelligent sensors that contributes to the development of optimal data processing algorithms based on increasingly complex stochastic models of an impact on a sensor. An alternative to this strategy is a method of smart sensors implementation using neural networks. Functioning of intelligent sensors is provided by using actual data, which characterize a physical object of research.

It is necessary to perform the following steps for creation of algorithms:

- determination of operation modes of intelligent measuring system in a variety of situations, including an extreme ones;

- training of a smart sensor considering peculiarities of a process of research;

- formation of logic of diagnostics system functioning in case of failure of some sensor.

The basis of intelligent humidity sensor (IHS) hardware is a MSP430 microcontroller from Texas Instruments. This device uses SH15 humidity and temperature sensors from Sensirion, external ones to measure the initial temperature and humidity of drying agent and internal ones to measure the current temperature and humidity in the sections. There is also a conveyor speed sensor, a general exhaust fan switching-on sensor, common to the entire dryer, as well as individual sensors of controlled cameras: degree of opening of release gates and air intake windows. The required information is stored in non-volatile DataFlash memory device.

One of important properties of the monitoring system is a self-diagnostics feature. The ability to self-control characterizes a property of sensor to retain the characteristics within acceptable limits for a consumer in the event of sensor or information channel failure.

Evaluation of pasty material humidity is carried out using a neural network with multilayer perceptron architecture, trained by back propagation algorithm. 
Network inputs are normalized values: $x_{1}$ is initial humidity of material, $x_{2}, x_{3}$ are ambient temperature and humidity, $x_{4}$ is speed of a plate conveyor, $x_{5}$ is switching on or off of agitator, $x_{6}$ is percent of time when exhaust fan works, $x_{7}, x_{8}$ are average weighted temperature and humidity of drying agent in the $i$-th camera; $x_{9}, x_{10}$ are percentage of opening of air intake window and release gate. Training of a neural network is organized by exemplary measures of technological parameters in the adaptive range of the $i$-th camera with fixed precision.

Data normalization is performed using the following formula:

$$
x_{q}^{\mathrm{n}}=x_{q} \cdot K_{\mathrm{amp}}^{\mathrm{n}}+K_{\mathrm{of}}^{\mathrm{n}}, \quad q=\overline{1, \Theta},
$$

where $q$ is serial number of network input; $x_{q}^{\mathrm{n}}, x_{q}$ are normalized and non-normalized values of $q$-th network input; $K_{\mathrm{amp}}^{\mathrm{n}}, K_{\mathrm{of}}^{\mathrm{n}}$ are amplitude and offset scaling factors; $\Theta$ is number of network inputs used to calculate humidity $\varphi_{i}^{\mathrm{k}}$ in $i$-th camera [2].

Analytical model of multilayer perceptron for evaluating moisture content in $i$-th camera, trained by algorithm that mentioned above, is represented as:

$$
\begin{aligned}
& \overline{\varphi_{i}}=\left[1+\exp \left(-\beta_{\text {out }}^{(i)}\left[\sum _ { j = 1 } ^ { N _ { i } } w _ { j } ^ { ( i \text { out } ) } \left(1+\exp \left(-\beta_{j}^{(i)}\left[w_{1, j}^{(i)} \overline{x_{1}}+w_{2, j}^{(i)} \overline{x_{2}}+w_{3, j}^{(i)} \overline{x_{3}}+w_{4, j}^{(i)} \overline{x_{4}}+\right.\right.\right.\right.\right.\right. \\
& \left.\left.\left.\left.\left.\left.+w_{5, j}^{(i)} \overline{x_{5}}+w_{6, j}^{(i)} \overline{x_{6}}+w_{7, j}^{(i)} \overline{x_{7}}+w_{8, j}^{(i)} \overline{x_{8}}+w_{9, j}^{(i)} \overline{x_{9}}+w_{10, j}^{(i)} \overline{x_{10}}\right]-\theta_{j}^{(i)}\right)\right)^{-1}\right]-\theta_{\text {out }}^{(i)}\right)\right]^{-1},
\end{aligned}
$$

where for sigmoidal activation functions of neurons are denoted by $\beta_{j}^{(n)}, \beta_{j}^{(n+1)}$ angles for hidden layer and $\beta_{\text {out }}^{(n)}, \beta_{\text {out }}^{(n+1)}$ - for output layer of neural network, $\theta_{j}^{(n)}$, $\theta_{j}^{(n+1)}$ - shifts for hidden layer and $\theta_{\text {out }}^{(n)}, \theta_{\text {out }}^{(n+1)}$ - for output layer of network; $w_{i, j}^{(n)}$, $w_{i, j}^{(n+1)}$ and $w_{j}^{(n \text { out })}, w_{j}^{(n+1 \text { out })}$ - weighting relation factors for hidden and output network layers, $N_{i}$ - number of neurons in hidden network layer when calculating moisture content in $i$-th camera of dryer; normalized values of material humidity data $\overline{\varphi_{i}}$, initial humidity of material $\overline{x_{1}}$, ambient temperature and humidity $\overline{x_{2}}, \overline{x_{3}}$; speed of a plate conveyor $\overline{x_{4}}$, switching on or off of agitator $\overline{x_{5}}$, percent of time when exhaust fan works $\overline{x_{6}}$, temperature and humidity of drying agent $\overline{x_{7}}, \overline{x_{8}}$, percentage of opening of air intake window and release gate $\overline{x_{9}}, \overline{x_{10}}$ [2].

Output of network is denormalized by the formula for obtaining data about material humidity in real-world units:

$$
\varphi_{i}=\frac{\bar{\varphi}_{i}-K_{\mathrm{of}}^{\mathrm{dn}}}{K_{\mathrm{amp}}^{\mathrm{dn}}},
$$

where $K_{\mathrm{amp}}^{\mathrm{dn}}, K_{\mathrm{of}}^{\mathrm{dn}}$ are amplitude and offset denormalizing factors [3].

The resulting analytical dependence (2) allows evaluating material humidity in $i$-th camera of dryer in real time during its drying. Similar models are made for other cameras.

Let us extend the set of humidity determination models to eliminate the significant impact on accuracy of failure of one or a group of sensors. Models of the form (2) are used in case of a faultless operation of sensors, where information from all sensors is 
used. In the event of failure of one or more sensors it is proposed to carry out calculations on models, which take into account these situations.

Let us distinguish four groups of sensors in order of importance of information coming from them to create an extended set of models.

Zero group is class of situations $G_{0}$ (trouble-free operation of all sensors).

First group is class of situations $G_{1}$ (soft sensor failures) includes sensors, information from which is interference on measurement channel, for example, external sensor of initial temperature and humidity of drying agent or sensor of switching on or off of agitator, that responsible for uniformity of the material layer on the tape. Off-season average temperature and humidity in workshop and average thickness of the paste are taken into account in the case of failure of sensors from that group.

Second group is class of situations $G_{2}$ (medium sensor failures) that includes windows and gates opening sensors, information from which represents dryer cameras setup.

If a failure occurs in this group of sensors, the models without taking into account the degree of opening of gates and windows in the sections are used.

Third group is class of situations $G_{3}$ (hard sensor failures) that includes conveyor speed, agitator switching on or off, temperature and humidity of drying agent in sections sensors, failure of which is most dangerous because it leads to errors of humidity measurement and drying process control.

Table shows the correspondences of classes with situations, missing model parameters and identifiers of models that used in this case.

Extended set of models includes the following models for $n$ and $n+1$ controlled cameras of following groups:

- $G_{0}$ is models $m_{1}$ and $m_{2}$ similar to model (2), wherein model $m_{1}$ output is model $m_{2}$ input.

- $G_{1}$ is models $m_{3}, m_{4}$, distinctive feature of which is obtaining information about initial temperature and humidity of drying agent not from sensors but from database. Model $m_{5}$ similar to $m_{1}$, but without taking into account an agitator;

\section{Classes of situations and failures of sensors}

\begin{tabular}{|c|c|c|c|}
\hline $\begin{array}{c}\text { Class } \\
\text { of situation }\end{array}$ & Situation & $\begin{array}{l}\text { Unknown model } \\
\text { parameter }\end{array}$ & $\begin{array}{c}\text { Model } \\
\text { identifier }\end{array}$ \\
\hline$G_{0}$ & $\begin{array}{l}\text { Trouble-free operation of all sensors of } \\
\text { IHS }\end{array}$ & - & $m_{1}, m_{2}$ \\
\hline \multirow{2}{*}{$G_{1}$} & $\begin{array}{l}\text { Failure of workshop temperature and } \\
\text { humidity sensor }\end{array}$ & $x_{2}, x_{3}$ & $m_{3}$ \\
\hline & $\begin{array}{l}\text { Failure of agitator switching on or off } \\
\text { sensor }\end{array}$ & $x_{5}$ & $m_{4}$ \\
\hline \multirow{3}{*}{$G_{2}$} & Failure of gates opening sensor & $x_{10}$ & $m_{5}, m_{6}$ \\
\hline & Failure of windows opening sensor & $x_{9}$ & $m_{7}, m_{8}$ \\
\hline & Failure of initial material humidity & $x_{1}$ & $m_{9}$ \\
\hline \multirow{3}{*}{$G_{3}$} & Failure of conveyor speed sensor & $x_{4}$ & $m_{10}$ \\
\hline & $\begin{array}{l}\text { Failure of exhaust fan switching on or off } \\
\text { sensor }\end{array}$ & $x_{6}$ & $m_{11}$ \\
\hline & $\begin{array}{l}\text { Failure of temperature and humidity of } \\
\text { drying agent sensor in sections }\end{array}$ & $x_{7}, x_{8}$ & $m_{12}, m_{13}$ \\
\hline
\end{tabular}




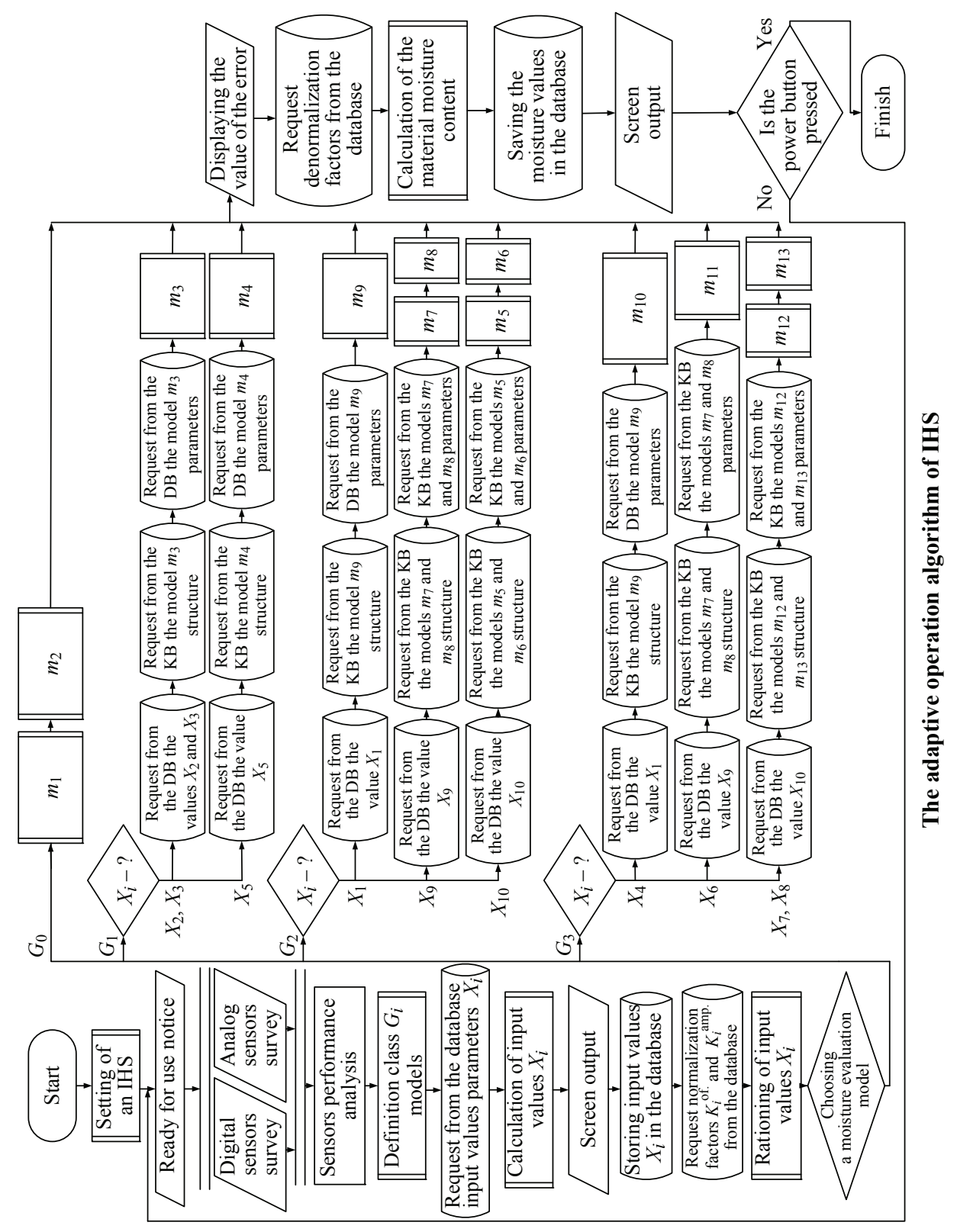


- $G_{2}$ is models $m_{6}$ and $m_{7}$ without taking into account changing of opening degree of release gates; models $m_{8}$ and $m_{9}$ without taking into account opening degree of air intake windows in $n$ and $n+1$ sections respectively;

- $G_{3}$ is model $m_{10}$ without taking into account operation periodicity of exhaust fan, model $m_{11}$ without taking into account an exhaust fan work, model $m_{12}$ without taking into account drying agent temperature, model $m_{13}$ without taking into account drying agent humidity.

Thus, if a failure occurrs in the process of sensors survey, then the model from the knowledge base of IHS is automatically selected, by which pasty material humidity is determined with an acceptable error. As a result of the adaptive algorithm work IHS is a fault-tolerant system. The adaptive operation algorithm of IHS is shown in Figure.

An IHS during a pasty material drying in a drum-tape dryer implemented at JSC "Pigment" (Tambov); its use has allowed increasing the production of quality products.

Thus, a technical task of rapid assessment of a moving pasty material humidity during its drying in real time is reached in order to ensure the quality of the resulting material.

The work was partially supported by the RFBR grant № 14-08-00198-a.

\section{References}

1. Selivanova Z.M., Samohvalov V.A. Measurement Techniques, 2012, vol. 55, no. 9, pp. 1049-1056. doi: 10.1007/s11018-012-0073-1.

2. Artemova S.V., Gribkov A. N., Bryankin K.V., Nazarov A.S., Tambov State Technical University, Sposob otsenki vlazhnosti pastoobraznogo materiala v protsesse ego sushki v val'tse-lentochnoi sushil'noi ustanovke (A method of evaluating of a pasty material humidity in a process of drying in a drum-tape dryer), Russian Federation, 2012, Pat. 2444725

3. Artemova S.V., Nazarov A.S., Podhvatilin P.A. Voprosy sovremennoi nauki i praktiki. Universitet imeni V.I. Vernadskogo, 2011, spec. issue (36), pp. 7-12.

\section{Адаптивный алгоритм функционирования интеллектуального датчика влажности}

\section{С. В. Артемова, А. А. Артемов, П. А. Подхватилин, И. Ю. Кошелев}

Кафедра «Конструирование радиоэлектронных и микропроцессорных систем», ФБГОУ ВПО «ТГТУ»; sartemova@yandex.ru

Ключевые слова: адаптивный алгоритм; интеллектуальный датчик; нейронная сеть; отказ датчика.

Аннотация: Приведен адаптивный алгоритм функционирования интеллектуального датчика влажности, позволяющий в случае отказа компонентов устройства с приемлемой погрешностью определять влагосодержание пастообразного материала.

\section{Список литературы}

1. Селиванова, 3. М. Интеллектуальная информационно-измерительная система для определения теплофизических свойств материалов и изделий / 3. М. Селиванова, В. А. Самохвалов // Измер. техника. - 2012. - № 9. - С. 38 - 42 . 
2. Пат. 2444725 Российская Федерация, МПК G01N2500. Способ оценки влажности пастообразного материала в процессе его сушки в вальце-ленточной сушильной установке / Артемова С. В., Грибков А. Н., Брянкин К. В., Назаров А. С. ; заявитель и патентообладатель Тамб. гос. техн. ун-т. № 2010109120/28(012771) ; заявл. 10.03.2010 ; опубл. 10.03.12, Бюл. № 7. - 16 c.

3. Артемова, С. В. Микропроцессорная система мониторинга влажности пастообразных материалов / С. В. Артемова, А. С. Назаров, П. А. Подхватилин // Вопр. соврем. науки и практики. Университет им. В.И. Вернадского. - 2011. Спец. вып. (36). - С. 7 - 12.

\section{Adaptiver Algorithmus des Funktionierens des intellektuellen Feuchtigkeitsensors}

Zusammenfassung: Es ist den adaptiven Algorithmus des Funktionierens des intellektuellen Feuchtigkeitsensors, der im Fall des Versagens von den Anlagekomponenten mit dem annehmbaren Fehler den Feuchtegehalt zu bestimmen erlaubt, angeführt.

\section{L'algorithme adaptatif du fonctionnement de la sonde intellectuelle d'humidité}

Résumé: Est donné un algorithme adaptatif du fonctionnement de la sonde intellectuelle d'humidité permettant en cas de défaillance des composants de l'appareil de déterminer la teneur en eau de la matière pâteuse avec une précision acceptable.

Авторы: Артемова Светлана Валерьевна - доктор технических наук, профессор кафедры «Конструирование радиоэлектронных и микропроцессорных систем»; Артемов Анатолий Анатольевич - доктор технических наук, профессор ФГБОУ ВПО «Тамбовский государственный университет им. Г. Р. Державина»; Подхватилин Павел Александрович - магистрант кафедры «Конструирование радиоэлектронных и микропроцессорных систем»; Кошелев Игорь Юрьевич студент, ФГБОУ ВПО «ТГТУ».

Рецензент: Муромцев Дмитрий Юрьевич - доктор технических наук, профессор, проректор по научно-инновационной деятельности, ФГБОУ ВПО «ТГТУ». 